\title{
Fisheries of experimental purse seine net using light and population dynamics of Sardinella aurita (Family Clupeidae) east of Alexandria, Egypt.
}

\author{
EL- Sayed H. Kh. Akel \\ National Institute of Ocean.\& Fish., Alex., Egypt
}

\begin{abstract}
$\mathrm{T}$ he present study is focused on investigating the fisheries of pelagic fish caught by purse seiners using light from Alexandria to Rosetta during 2007. Five experimental fishing operations were processed seasonally (spring, summer and autumn).The fishing operation and sampling were explained. Analysis of species composition (seasonal and total) and size composition were carried out. A comparison between the present study and other previous studies was done. The average catch of the net per night was maximum during summer $(1295 \mathrm{Kg})$, while minimum one during autumn $(479 \mathrm{Kg})$. The most abundant fish in the catch throughout the year was Sardinella aurita followed by Etrumeus teres, Sardina pilchardus, Scomber japonicus, Boops boops, Trachurus mediterraneus, and Engraulis encrasicholus respectively.

Growth and dynamic parameters of S. aurita, as it is the main economic pelagic fish species, were investigated. The results obtained show that back calculated lengths (based on scales readings) for the first, second, third, fourth and fifth age groups were $12.24 ; 15.9 ; 18.98 ; 21.36$ and $22.17 \mathrm{~cm}$ respectively. The corresponding weights for the same age groups were $14.31 ; 28.93 ; 46.57$; 63.98 and $70.71 \mathrm{gm}$ respectively. The length-weight relationship was represented by the formula:

$\log \mathrm{W}=0.01701+2.68904 \log \mathrm{L}$. The estimated von Bertalanffy growth parameters were $\mathrm{L} \infty=25.55 \mathrm{~cm} ; \mathrm{K}=0.3537$ year $^{-1}$ and to $=-0.81$. Growth performance: 2.368. Maximum age: 7.59 year. Total mortality $(\mathrm{Z})$, natural mortality $(\mathrm{M})$ and fishing mortality $(\mathrm{F})$ were: $1.467 ; 0.86959$ and 0.5974 respectively. The yield per recruit indicated that maximum sustainable yield was $18.5 \mathrm{~g}$ at fishing mortality (F) 2.8 .Maximum optimum yield was $16.7 \mathrm{~g}$ at fishing mortality 1.2 . The current yield was $13.5 \mathrm{~g}$ at fishing mortality 0.597 . Meanwhile biomass was $22.6 \mathrm{~g}$ at exploitation rate $0.313 ; 13.9 \mathrm{~g}$ at exploitation rate 0.51 and $6.6 \mathrm{~g}$ at exploitation rate of 0.74 respectively. The exploitation rate (E): 0.31336 proved that this species is under exploitation by purse seine using light.
\end{abstract}

Key words: purse seine fisheries, population dynamics, Sardinella aurita, Alexandria. 


\section{INTRODUCTION}

The term "purse seine" means fishing net used to encircle pelagic fish. It was set at speed from a large powered vessel during the retrieval; the net bottom is closed and pursed by drawing a purse rope through a series of rings to prevent fish escaping.

Purse seiners using light had been enhanced in the Red Sea during 1960 and during 1969 in the Mediterranean Egyptian waters (Rafail, 1972) to compensate the war conditions in 1967 and the reduction of the Nile flood sediments resulted from construction of the High Dam $(1964-1966)$. Various factors affect the degree of light attraction on fish. Cushing \& Verheijen (1960) showed that the degree of fish attraction to light is related to the intensity of light source and its wave lengths. Imamura \& Takeuchi (1960) reported that time of illumination has an effect on fish attraction. It must be mentioned that this fishing method does not operate during winter time due to bad and stormy weather. Also, during approximately ten days monthly, when the moon is full, the fishing operations cease.

The purse seine (Shansholla) fishery has become one of the most important fisheries in the Egyptian Mediterranean waters as it is adapted mainly to capture pelagic fish. It contributes about $44 \%$ of the total Egyptian Mediterranean catch (GAFRD, 2007).

This work aimed to assess the population dynamics of the most dominant and economic sardine species: Sardinella aurita regarding its growth, mortality, yield per recruit and biomass.

\section{MATERIAL AND METHODS}

Five fishing operations were processed seasonally, using commercial vessels with horse power range between 180 and $425 \mathrm{hp}$ from Alexandria to Rosetta.

\section{a-Study area:}

The area of investigation extended from Alexandria eastward to Rosetta $(55 \mathrm{Km})$ with depth range between 41 and $58 \mathrm{~m}$ (Fig.1). The fishing vessel used the echo sounder and radar to detect depth and the course of sailing.

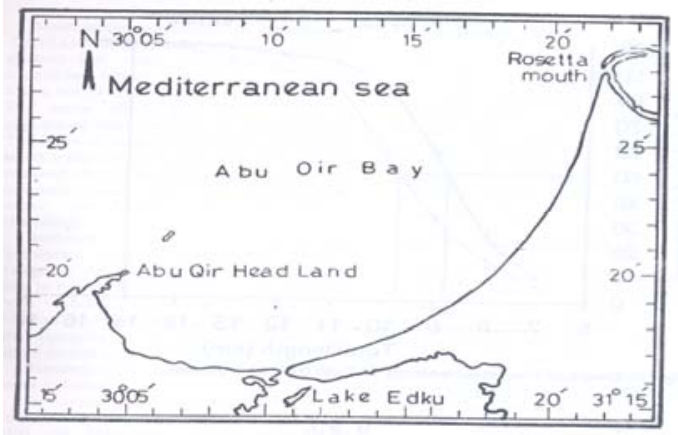

Fig. (1) Area of investigation 


\section{b - The fishing operation:}

All fishing ships were equipped with electric light range in number from 11 to 16 . Each spot has light intensity 400 watt. The mother ship has three rowing small boats. Each boat was equipped with 10 butane gas lamps or electric generator to light these 10 lamps instead of gas. The fishing vessel was manned by about 27 - 34 fisherman. Sailing started afternoon to reach the fishing ground before sunset near Rosetta. The first rowing small boat with 2 men was left in a fixed place, at a distance of about $500 \mathrm{~m}$; the second boat was left with other 2 men. Apart from the second boat of about $500 \mathrm{~m}$, the mother ship anchors itself. On the mother ship, the electric generator operated to light the spots with about 4400 to 6400 watt during the period from sunset to before moon rise. Light attracts fish around the ship and the boats too. Before moon rise, as the ship releases the third lighted boat to the water, light spots were off gradually to collect and gather the catch around the released lighted boat .The ship encircled the lighted boat, while shooting the net quickly until all the net was set.The net bottom was then quickly closed by pursing it to prevent the fish escape. After pursing the net it was hauled from both ends by fishermen quickly with the catch in it. On deck, the catch was sorted according to species and size into different categories in wooden trays. The ship undergoes the same operation by encircling the other lighted two boats which were spaced before in the sea and collected the attracted fish around them.

\section{c- Sampling:}

After ending the fishing operation, two wooden trays of the catch on deck were taken before sorting as random sample. The sample was taken fresh and examined in the laboratory. Fish were identified to species. Total length and gutted weight was recorded to the nearest millimeter and gram .The length frequency distribution was determined at $1.0 \mathrm{~cm}$ length intervals.

For Sardinella aurita; total length and gutted weight to the nearest $\mathrm{cm}$ and gram were recorded. Scales were taken from behind the pectoral fin. Examination of the scales was carried out by a binocular microscope (magnification power X 25). Fish were dissected to determine sex. To calculate length - weight relationship and condition factor for S.aurita, the commonly used equation: $\mathrm{W}=\mathrm{a} \mathrm{L}^{\mathrm{b}}$ was applied, where $\mathrm{W}=$ the gutted weight $(\mathrm{g}), \mathrm{L}$ is the total length $(\mathrm{cm})$ and $\mathrm{a} \& \mathrm{~b}$ are constants computed by (Le Cren, $1951 \&$ Ricker, 1975). Condition factor was estimated according to Fulton (1902): $\mathrm{K}=\mathrm{W} / \mathrm{L}^{3} \times$ 100 , where $\mathrm{K}=$ condition factor; $\mathrm{W}=$ gutted weight in $\mathrm{g}$ and $\mathrm{L}=$ total length of the fish in $\mathrm{cm}$. Estimates of the asymptotic length $\left(\mathbf{L}_{\infty}\right)$, growth coefficient $(\mathrm{K})$ and the hypothetical age (to) of fish at zero length were computed according to Gulland method (1969).Theoretical growth was calculated using the von Bertalanffy equation developed by Beverton \& Holt (1957). The reliability of these growth parameters was tested by Munro" phi index $(\varnothing)$ computed from the equation derived by Pauly \& Munro (1984): $\varnothing=\log \mathrm{K}+2 \log \mathrm{L}_{\infty}$. The maximum age (tmax $=3 / \mathrm{K}+$ to) was estimated using the growth coefficient 
(K) after Pauly (1983). Rate of total mortality (Z) was calculated from the catch curve as described by Pauly (1983). The computed value of annual rate of mortality derived from the equation: $\mathrm{A}=1-\mathrm{e}^{-\mathrm{z}}$.

The survival rate was estimated from the equation $S=e^{-z}$. The rate of natural mortality (M) was computed according to the equation suggested by Pauly (1980):

$\log M=-0.0066-0.279 \log \mathrm{L}_{\infty}+0.6543 \log \mathrm{K}+0.4634 \log \mathrm{T}$. The rate of fishing mortality (F) was extracted as $\mathrm{F}=\mathrm{Z}-\mathrm{M}$. The exploitation ratio (E) was calculated as equal to the fraction of death caused by fishing: $\mathrm{E}=\mathrm{F} \mathrm{A} / \mathrm{Z}$ (Cushing, 1968). Length at first capture (Lc) was estimated according to Beverton \& Holt (1957) : $\mathrm{Lc}=\mathrm{L}^{-}-\mathrm{K}\left(\mathrm{L}_{\infty}-\mathrm{L}^{-}\right) / \mathrm{Z}$, where $\mathrm{L}^{-}$is the mean length of the catch, $\mathrm{K}$ and $\mathrm{L} \infty$ are the growth parameters of von Bertalanffy equation and $\mathrm{Z}$ is the rate of total mortality. The corresponding age at first capture (tc) was calculated as: $t c=-1 / \mathrm{K} \ln \left(1-\mathrm{Lc} / \mathrm{L}_{\infty}\right)+$ to. Length at recruitment $(\mathrm{Lr})$ was determined graphically from the cumulative curve of proportion against total length. The corresponding age at recruitment (tr) was estimated from the equation: $\operatorname{tr}=-1 / \mathrm{K} \ln \left(1-\mathrm{Lr} / \mathrm{L}_{\infty}\right)+$ to.

\section{Yield per recruit}

Gulland (1969) estimated the yield per recruit from the Beverton \& Holt (1957) model as follows:

$$
\begin{aligned}
& \mathrm{Y} / \mathrm{R}=\mathrm{F}\left(\mathrm{e}^{-\mathrm{M}(\mathrm{tc}-\mathrm{tr})}\right) \mathrm{W}_{\infty}\left\{1 / \mathrm{Z}-3 \mathrm{~S} /(\mathrm{Z}+\mathrm{K})+3 \mathrm{~S}^{2} /(\mathrm{Z}+2 \mathrm{~K})-\mathrm{S}^{3} /(\mathrm{Z}+3 \mathrm{~K})\right\}, \\
& \mathrm{S}=\mathrm{e}^{-\mathrm{K}(\mathrm{tc}-\mathrm{to})} \\
& \text { Where, } \mathbf{Y}=\text { yield in gram. } \\
& \mathbf{R}=\text { number of recruits. } \\
& \mathbf{F}=\text { fishing mortality coefficient. } \\
& \mathbf{M}=\text { natural mortality. } \\
& \mathbf{t c}=\text { age at first capture } \\
& \mathbf{t r}=\text { age at recruitment. }
\end{aligned}
$$

\section{Biomass (B):}

It is defined as the weight of the living stock and derived by dividing the yield per recruit (Y/R) by the corresponding fishing mortality (Ricker, 1975).

\section{A - Fisheries of pelagic fishes: \\ 1 - Species composition of the catch:}

\section{RESULTS}

Table (1) and Figure (2) illustrate seasonal and total average catch of five commercial purse seiners operations. The total number of species recorded was seventeen species. 
Table (1) Seasonal and total catch $(\mathrm{Kg})$ by purse seine net using light, east of AlexandriaEgypt (2007).

\begin{tabular}{|c|c|c|c|c|c|c|c|c|c|c|c|c|}
\hline \multirow{3}{*}{ Species } & \multicolumn{3}{|c|}{ Spring } & \multicolumn{3}{|c|}{ Summer } & \multicolumn{3}{|c|}{ Autumn } & \multicolumn{3}{|c|}{ Total } \\
\hline & \multirow{2}{*}{$\begin{array}{l}\text { Total } \\
\text { catch } \\
\text { (kg) }\end{array}$} & \multicolumn{2}{|c|}{$\begin{array}{l}\text { Av. catch per } \\
\text { night }\end{array}$} & \multirow{2}{*}{$\begin{array}{l}\text { Total } \\
\text { catch } \\
\text { (kg) }\end{array}$} & \multicolumn{2}{|c|}{$\begin{array}{l}\text { Av. catch per } \\
\text { night }\end{array}$} & \multirow{2}{*}{$\begin{array}{l}\text { Total } \\
\text { catch } \\
\text { (kg) }\end{array}$} & \multicolumn{2}{|c|}{$\begin{array}{l}\text { Av. catch per } \\
\text { night }\end{array}$} & \multirow{2}{*}{$\begin{array}{l}\text { Total } \\
\text { catch } \\
\text { (kg) }\end{array}$} & \multicolumn{2}{|c|}{$\begin{array}{l}\text { Av. catch } \\
\text { per night }\end{array}$} \\
\hline & & $(\mathrm{kg})$ & $\%$ & & $(\mathrm{~kg})$ & $\%$ & & $(\mathrm{~kg})$ & $\%$ & & $(\mathrm{~kg})$ & $\%$ \\
\hline S. aurita & 240 & 48 & 16.2 & 5550 & 1110 & 85.98 & 75 & 15 & 3.13 & 5865 & 1173 & 44.51 \\
\hline S. pilchardus & 700 & 140 & 5.6 & 230 & 46 & 3.55 & 560 & 112 & 23.4 & 1490 & 298 & 11.30 \\
\hline E. teres & 1754 & 350.8 & 40.6 & 305 & 61 & 4.71 & 55 & 11 & 2.3 & 2114 & 422.8 & 16.04 \\
\hline H. punctatus & & & & & & & 2 & 0.4 & 0.08 & 2 & .4 & 0.015 \\
\hline D.acuta & & & & 3.55 & 0.71 & 0.06 & & & & 3.55 & .71 & 0.026 \\
\hline $\begin{array}{l}\text { Total sardine } \\
\text { catch }\end{array}$ & 2694 & 538.8 & 62.4 & 6088.6 & 1217.7 & 94.03 & 692 & 138.4 & 28.9 & 9474.55 & 1894.91 & 71.90 \\
\hline B. boops & 400 & 80 & 9.3 & 10 & 2 & 0.15 & 960 & 192 & 40.1 & 1370 & 274 & 10.40 \\
\hline S .japonicus & 987 & 197.4 & 22.9 & 75 & 15 & 1.16 & 320 & 64 & 13.37 & 1382 & 276.4 & 10.49 \\
\hline T.mediterraneus & 60 & 12 & 1.3 & 20 & 4 & 0.31 & 400 & 80 & 16.71 & 480 & 96 & 3.64 \\
\hline E.encrasicholus & 140 & 28 & 3.2 & 255 & 51 & 3.94 & 1.0 & 0.2 & 0.04 & 396 & 79.2 & 3.01 \\
\hline T. saltator & & & & 17 & 3.4 & 0.26 & & & & 17 & 3.4 & 0.13 \\
\hline S.sphyraena & 6 & 1.2 & 0.13 & & & & 4.0 & 0.8 & 0.17 & 2 & 2 & 0.075 \\
\hline A. djedaba & & & & & & & 10 & 2 & 0.42 & 10 & 2 & 0.075 \\
\hline E.alletratus & & & & & & & 2.5 & 0.5 & 0.1 & 2.5 & 0.5 & 0.019 \\
\hline T.ovatus & & & & & & & 2.5 & 0.5 & 0.1 & 2.5 & 0.5 & 0.02 \\
\hline others* & 28 & 5.6 & 0.6 & 2.5 & 0.5 & 0.12 & 2.0 & 0.4 & 0.08 & 32.5 & 6.5 & 0.25 \\
\hline Total catch (kg) & \multicolumn{3}{|c|}{4315} & \multicolumn{3}{|c|}{6475.55} & \multicolumn{3}{|c|}{2394} & \multicolumn{3}{|c|}{13184.55} \\
\hline $\begin{array}{l}\text { Average catch } \\
\text { ( kg ) }\end{array}$ & \multicolumn{3}{|c|}{863} & \multicolumn{3}{|c|}{1295.11} & \multicolumn{3}{|c|}{478.8} & & & \\
\hline $\begin{array}{l}\text { Number of } \\
\text { boats }\end{array}$ & \multicolumn{3}{|c|}{5} & \multicolumn{3}{|c|}{5} & \multicolumn{3}{|c|}{5} & & & 15 \\
\hline
\end{tabular}

* Belone acuse

Loligo vulgaris

Scomberomorus commerson

The total catch during the three seasons was $13185 \mathrm{~kg}$ and the maximum production was in summer $(6476 \mathrm{~kg})$, followed by spring $(4315 \mathrm{~kg})$ and the minimum catch obtained in autumn $(2394 \mathrm{~kg})$. Sardine species dominated the catch by about $72 \%$; S. aurita (44.51\%); E. teres $(16.04 \%)$; S. pilchardus $(11.30 \%)$ and both Herklotsichthys punctatus and Dussumeria acuta acquired $0.04 \%$. Although $S$. pilchardus was caught in large amount but the catch composed of small sized fish of low value. S. aurita is the economic dominant species of Sardine. Among other species caught, S. japonicus was represented by 
(10.5\%) followed by B. boops (10.4\%); T. mediterraneus and E. encrasicholus $(3.6 \%$ and $3 \%)$ respectively.

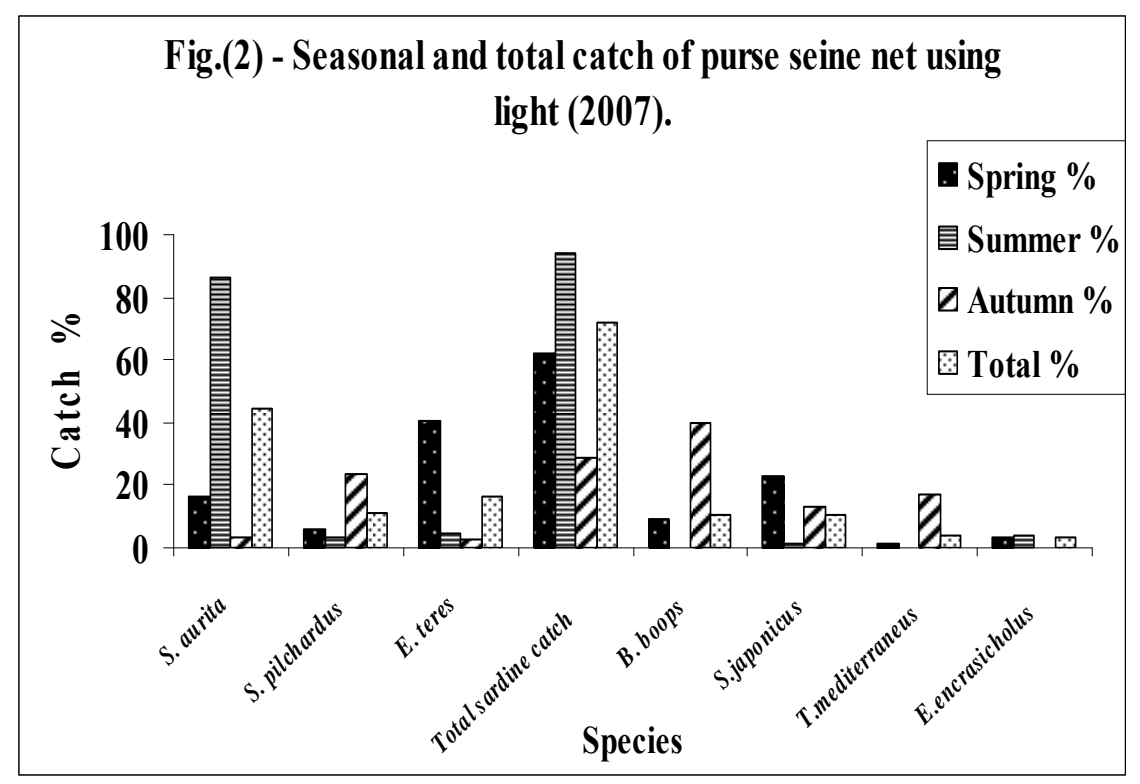

The seasonal average catch ranged from 479 to $1295 \mathrm{~kg} / \mathrm{night} /$ boat. It was noticed that sardine species dominated the catch during the three seasons with maximum percentage in summer (94\%) while lower value was attained in autumn (29\%). B. boops acquired higher value in autumn (40\%) and lower value in summer $(0.2 \%)$. S. japonicus caught attained higher percentage during spring $(23 \%)$ and lower value $(1.2 \%)$ in summer. T. mediterraneus reached high percentage in the catch during autumn $(16.7 \%)$, while lower values were attained during spring and summer $(1.3 \%, 0.3 \%)$ respectively. E.encrasicholus got its higher percentage in the catch during summer $(4 \%)$ while lower value was found during spring and autumn $(3.2 \%$ and $0.04 \%)$ respectively.

\section{2 - Size composition:}

\section{2- i - Size composition of $S$. aurita:}

Data of length frequency analysis is given in Fig. (3). S. aurita size varied between 10 and $26 \mathrm{~cm}$ with an average length of $14.5 \mathrm{~cm}$. The size distribution was found to be unimodal with maximum length at $14 \mathrm{~cm}$. During spring, the fish measured from 12 to $26 \mathrm{~cm}$, with bimodal distribution at 14 and $17 \mathrm{~cm}$ with an average length of $15.2 \mathrm{~cm}$. For summer size ranged between 10 and $19 \mathrm{~cm}$ with an average length of $14 \mathrm{~cm}$. Regarding autumn, the fish size varied between 14 and $20 \mathrm{~cm}$ with an average length of $16.3 \mathrm{~cm}$. 


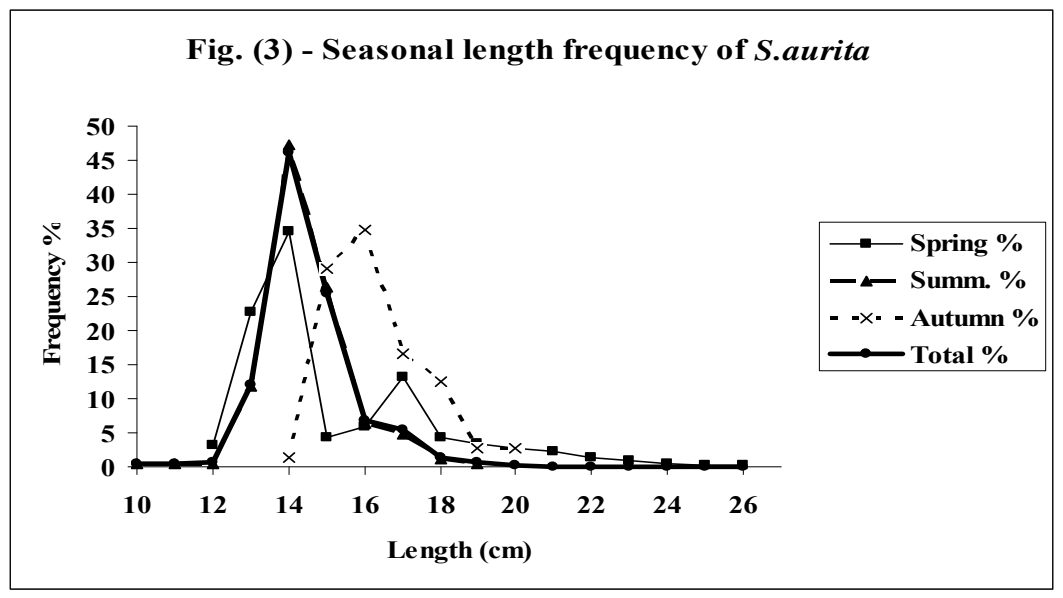

\section{2- ii - Size composition of $E$. teres:}

Most individuals belonging to this species ranged between 11 and $23 \mathrm{~cm}$ in length with an average value of $17.9 \mathrm{~cm}$. The size distribution showed bimodal distribution at 13 and $19 \mathrm{~cm}$ (Fig. 4). During spring, the of size varied between 12 and $23 \mathrm{~cm}$ with maximum at $19 \mathrm{~cm}$ with an average length of 18.3 $\mathrm{cm}$. Regarding summer, the size ranged between 13 and $15 \mathrm{~cm}$ with a maximum value at $13 \mathrm{~cm}$ with an average value of $13.4 \mathrm{~cm}$.Viewing autumn, the length varied between 11 and $22 \mathrm{~cm}$ with maximum at $14 \mathrm{~cm}$ with an average value of $15.8 \mathrm{~cm}$. The sizes showed a unimodal distribution.

The length -weight relationship of E.teres was found to be:

$$
\log \mathrm{W}=0.00714+3.0553 \log \mathrm{L}
$$

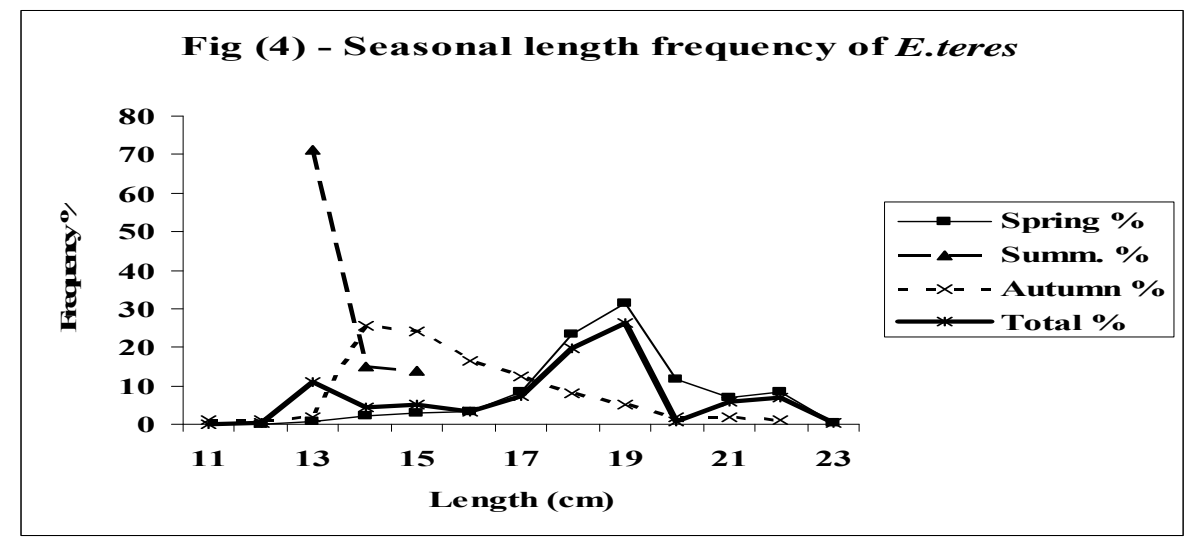




\section{2 - iii - Size composition of S. pilchardus:}

From Figure (5) it is evident that the fish size ranged between 8 and $15 \mathrm{~cm}$ with an average length of $11.8 \mathrm{~cm}$. The total length frequency distribution showed bimodal distribution at 9 and $11.5 \mathrm{~cm}$. For spring, the size varied between 11 and $15 \mathrm{~cm}$ with an average length of $12.7 \mathrm{~cm}$. As for summer, the fish measured between 8 and $11 \mathrm{~cm}$ with an average length of $8.9 \mathrm{~cm}$.Regarding summer, the fish length ranged between 11 and $13 \mathrm{~cm}$ with an average length of $11.8 \mathrm{~cm}$. The length-weight relationship of S. pilchardus was found to be: $\log$ $\mathrm{W}=0.08256+2.0551 \log \mathrm{L}$.

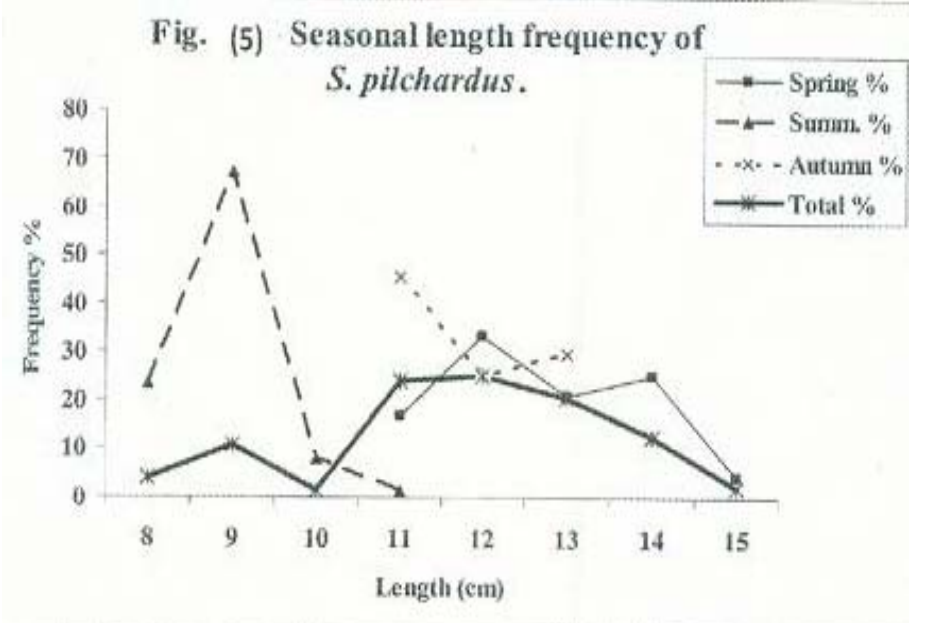

\section{2 - iv - Size composition of B. boops:}

The analysis of size composition of B. boops as shown from Fig. (6) revealed that the total size ranged between 7 and $18 \mathrm{~cm}$, with an average length of 14.cm. As for spring, the length varied between 9 and $17 \mathrm{~cm}$, with an average length of $13.13 \mathrm{~cm}$. Regarding summer, the fish size varied between 7 and 18 $\mathrm{cm}$, with an average length of $13.2 \mathrm{~cm}$. During autumn, the size ranged between 10 and $18 \mathrm{~cm}$, with an average length of $14.5 \mathrm{~cm}$.

The length-weight relationship of $B$. boops was found to be:

$\log \mathrm{W}=0.0318+2.4834 \log \mathrm{L}$

Fig.(6) - Seas onal length frequency of $B$. boops .

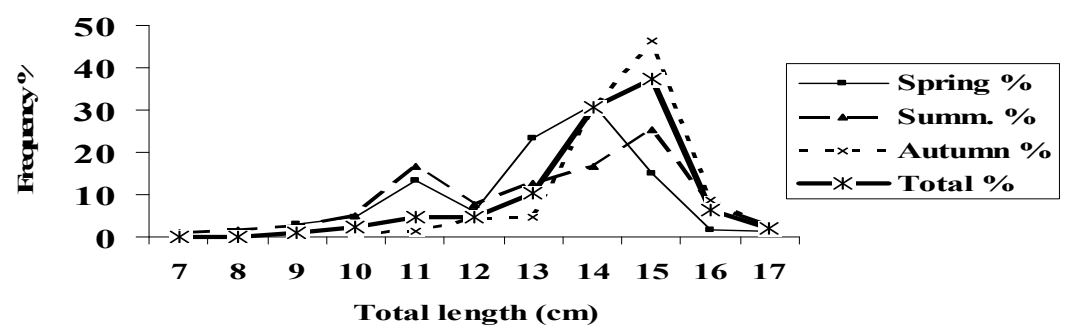




\section{2 - v - Size composition of S. japonicus:}

From Fig. (7), the total size frequency distribution of $S$ japonicus ranged between 12 and $29 \mathrm{~cm}$ with an average length of $22.2 \mathrm{~cm}$, with maximum at 22 $\mathrm{cm}$. During spring, the size varied between 18 and $29 \mathrm{~cm}$, with an average length $22.5 \mathrm{~cm}$. In summer, the fish size ranged between 12 and $21 \mathrm{~cm}$, with an average length of $16.5 \mathrm{~cm}$. Regarding autumn, the size varied between 19 and 27 $\mathrm{cm}$, with an average length of $22.4 \mathrm{~cm}$.

The length -weight relationship of S. japonicus was found to be:

$$
\log \mathrm{W}=0.00265+3.37211 \log \mathrm{L}
$$

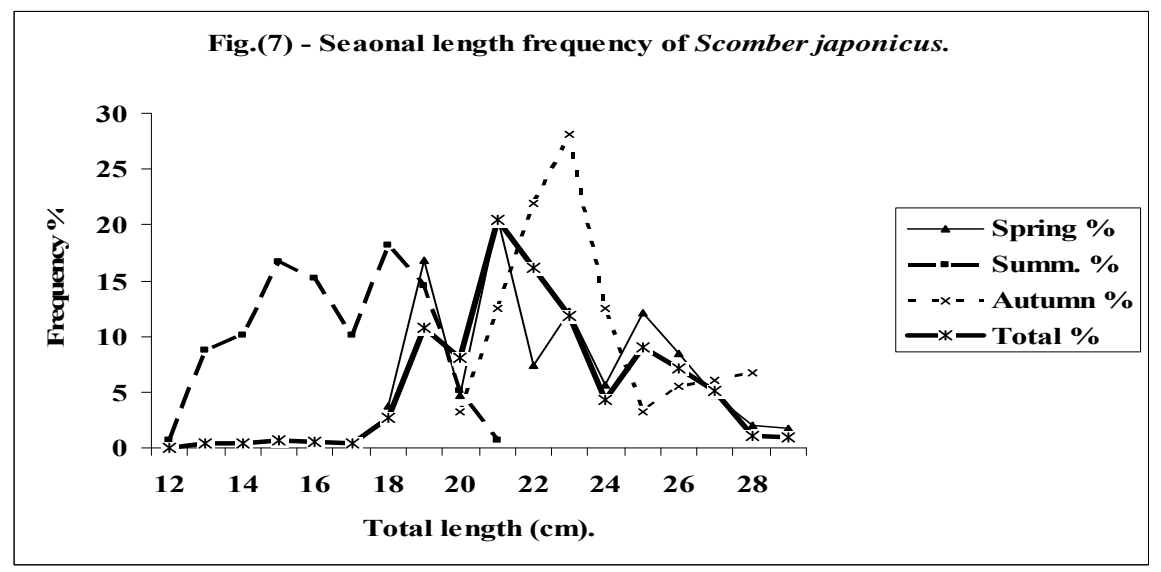

\section{2 - vi- Size composition of $T$. mediterraneus:}

From Fig. (8), the total size frequency analysis of T. mediterraneus ranged between 7 and $24 \mathrm{~cm}$ with an average length of $18.5 \mathrm{~cm}$, with maximum at 21 $\mathrm{cm}$. Regarding spring, the size varied between 12 and $21 \mathrm{~cm}$, with a average length of $17.4 \mathrm{~cm}$.During summer, the size varied between 7 and $13 \mathrm{~cm}$, with an average length of $10.32 \mathrm{~cm}$. In autumn, the size ranged between 16 and $24 \mathrm{~cm}$, with an average length of $20 \mathrm{~cm}$. The length-weight relationship of T. mediterraneus was found to be: $\log \mathrm{W}=0.01075+2.93284 \log \mathrm{L}$

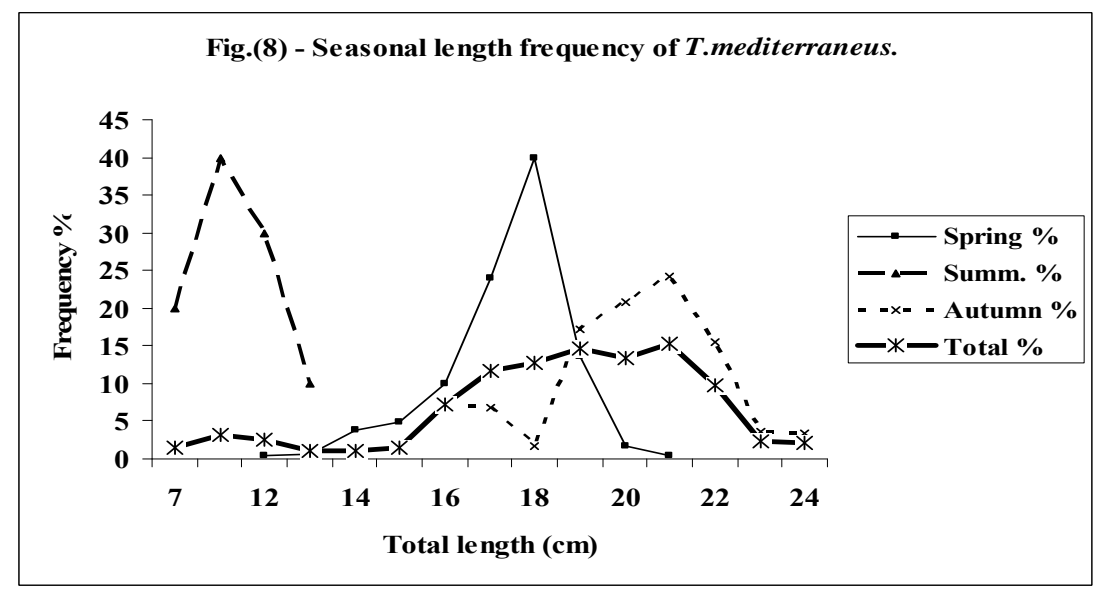




\section{2 - vii - Size composition of $E$. encrasicholus:}

From Fig. (9), the total size analysis of E. encrasicholus measured between 7 and $10 \mathrm{~cm}$, with an average length of $8.3 \mathrm{~cm}$. The frequency distribution showed the maximum value at $9 \mathrm{~cm}$. During spring, the size ranged between 8 and $10 \mathrm{~cm}$, with an average length of $8.9 \mathrm{~cm}$.Regarding summer, the size varied between 7 and $9 \mathrm{~cm}$, with an average length of $7.9 \mathrm{~cm}$.As for autumn, the size ranged between 8 and $10 \mathrm{~cm}$, with an average length of $9 \mathrm{~cm}$.

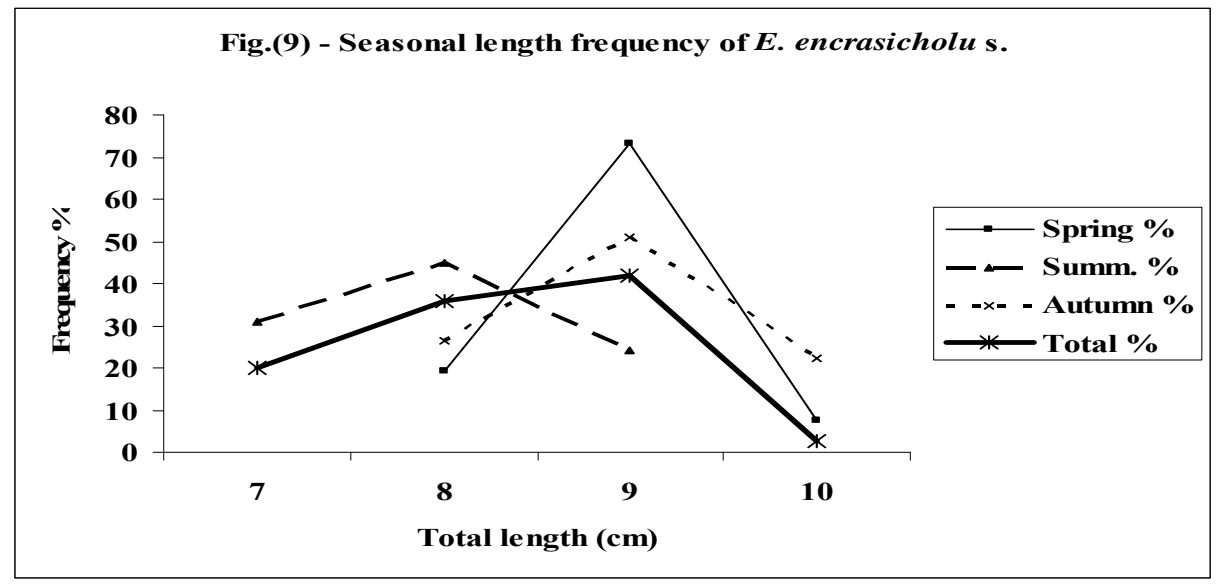

\section{B - Growth and dynamics of Sardinella aurita}

1 - Growth:

\section{1- i-Growth in length :}

Scales of 659 S.aurita from night purse seine catch were used to describe the relationship between total length and the scale radius. From Fig. (10) The relation was found to be linear and can be represented by the following equation: $\mathrm{L}=0.9630+2.0726 \mathrm{~S}(\mathrm{r}=0.9047)$.

Fig. (10) -Relation between total length and scale radius of $S$. aurita .

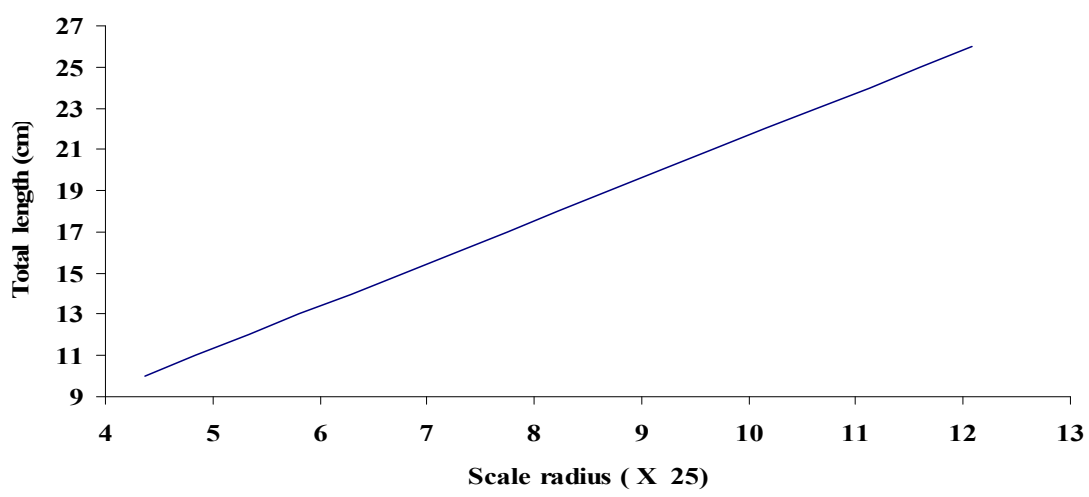


The back - calculated lengths using Lee's equation (1920) was as follows:

$$
\mathrm{Ln}=(\mathrm{L}-0.9630) \mathrm{Sn} / \mathrm{S}+0.9630,
$$

Where, Ln is the length at the end of $n$ year of life in $\mathrm{mm}$.

$\mathrm{Sn}$ is the radius of the scale to the $\mathrm{n}$ annulus in $\mathrm{mm}$.

$\mathrm{S}$ is the total radius of the scale.

and $\mathrm{L}$ is the total length at capture in $\mathrm{mm}$.

From Table (2) and fig. (11), it is evident that the maximum back calculated length was recorded by the end of first year of life $(12.24 \mathrm{~cm})$, after which a decrease in growth rate was noticed by increasing the age.

\section{1 - ii - Length - weight relationship:}

Analysis of data for 663 fish ranging between 10 and $26 \mathrm{~cm}$ using the gutted weight to exclude the effect of the intestine and gonads weight gave the following equations:

$$
\begin{array}{llc}
\text { For males } & \mathrm{W}=0.02878 \mathrm{~L}^{2.50039} & (\mathrm{r}=0.98454) \text {. } \\
\text { For females } & \mathrm{W}=0.00725 \mathrm{~L}^{2.9933} & (\mathrm{r}=0.99258) . \\
\text { For combined sexes } & \mathrm{W}=0.01701 \mathrm{~L}^{2.68904} & (\mathrm{r}=0.99251)
\end{array}
$$

Covariance analysis between observed weights of males and females showed significant difference between both sexes. Figure (12) shows the length -weight relationship for combined sexes of S.aurita during the whole seasons. Figure (13), for separate sexes, revealed that larger females were slightly heavier than males.

Condition factor: It was computed and found equal to 0.70 for S.aurita.

Table (2) - Calculated lengths (cm) at the end of each age group for S. aurita caught by purse seine net using light - east of Alexandria, 2007.

\begin{tabular}{|c|c|c|c|c|c|c|c|}
\hline Age & No. & Av.length & L1 & L2 & L3 & L4 & L5 \\
\hline I & 208 & 13.83 & 12.37 & & & & \\
\hline II & 342 & 16.56 & 12.27 & 16.02 & & & \\
\hline III & 83 & 19.7 & 12.16 & 15.88 & 19.32 & & \\
\hline IV & 22 & 22.8 & 11.79 & 14.51 & 17.95 & 21.68 & \\
\hline V & 4 & 24 & 11.66 & 13.92 & 17.84 & 19.59 & 22.17 \\
\hline \multicolumn{2}{|r|}{ Grand average } & 16.35 & 12.24 & 15.9 & 18.98 & 21.36 & 22.17 \\
\hline \multicolumn{2}{|r|}{ Increment } & & 12.24 & 3.66 & 3.08 & 2.38 & 1.81 \\
\hline
\end{tabular}




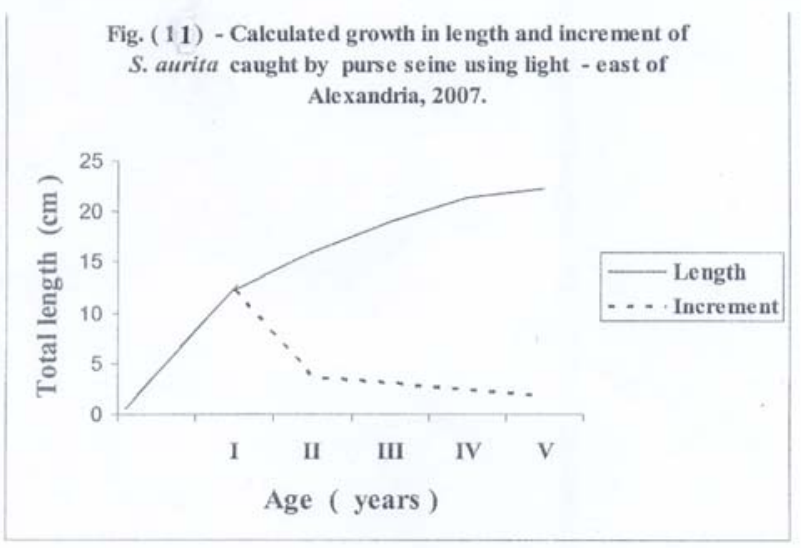

Fig. (12) - Length - weight relationship of S. aurita .
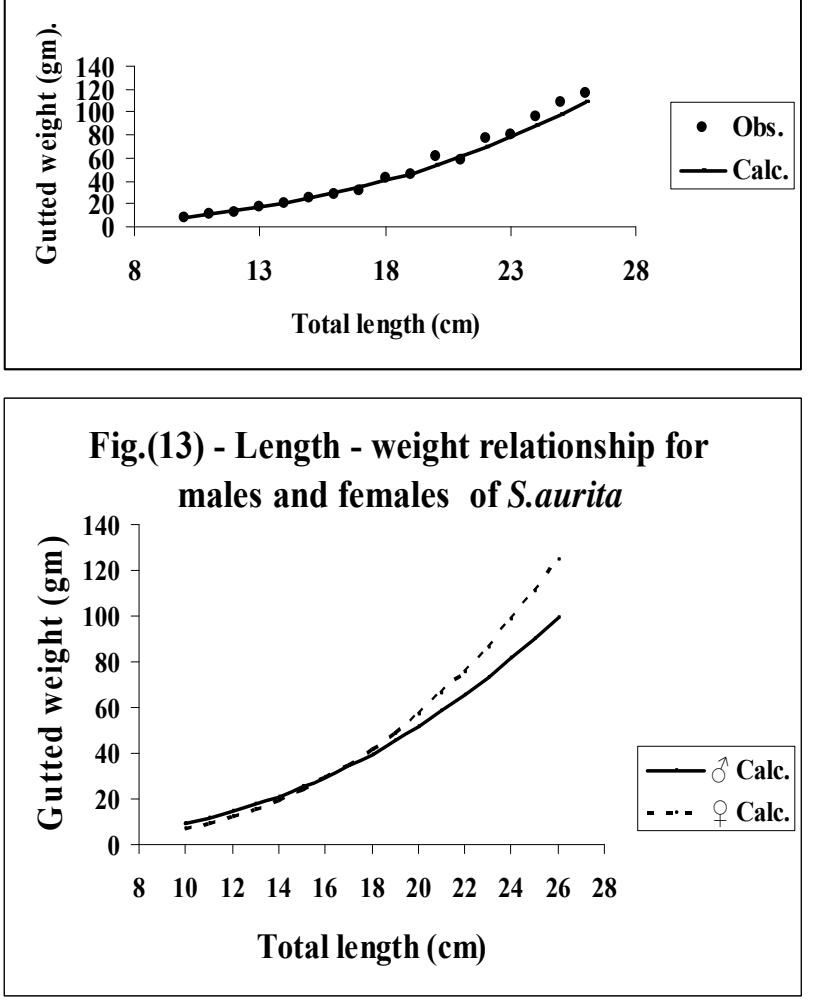


\section{1 - iii - Growth in weight:}

Table (3) and Fig. (14) show the calculated growth in weight using calculated lengths for $S$. aurita. The rate of putting on was minimal in the first year $(14.3 \mathrm{~g})$, then increased reaching maximum value in the third year of life $(17.6 \mathrm{~g})$, then it decreased to its minimum value in the fifth year of life (6.7 year).

Table (3) - Calculated weights (gm) at the end of each age group for S. aurita caught by purse seine net using light - east of Alexandria, 2007.

\begin{tabular}{|c|c|c|c|c|c|c|c|}
\hline Age & No. & Av.length & W1 & W2 & W3 & W4 & W5 \\
\hline I & 208 & 13.83 & 14.73 & & & & \\
\hline II & 342 & 16.56 & 14.41 & 29.52 & & & \\
\hline III & 83 & 19.7 & 14.06 & 28.83 & 48.84 & & \\
\hline IV & 22 & 22.8 & 12.94 & 22.62 & 40.08 & 66.59 & \\
\hline V & 4 & 24 & 12.56 & 20.23 & 39.42 & 50.7 & 70.71 \\
\hline \multicolumn{2}{r|}{ Grand average } & 16.35 & 14.31 & 28.93 & 46.57 & 63.98 & 70.71 \\
\hline Increment & & 14.31 & 14.62 & 17.64 & 17.41 & 6.73 \\
\hline
\end{tabular}

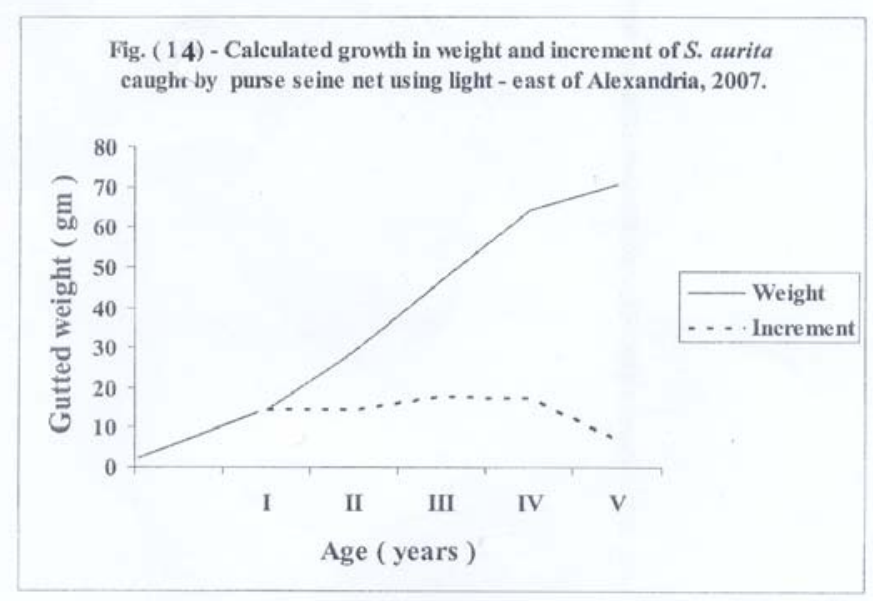

\section{1 - iv - Growth parameters:}

The von Bertalanffy growth parameters had been proved to be $\mathrm{L}^{\infty}=$ $25.55 \mathrm{~cm}, \mathrm{~K}=0.03573$, to $=-0.81$ and $\mathrm{W} \infty=103.56$ for maximum length, coefficient of growth, prenatal age and maximum weight respectively. The von Bertalanffy growth equation was used to evaluate the hypothetical lengths and weights at the different years of life as shown in Table (4). The obtained equations were as follows:

$$
\begin{aligned}
\mathrm{L}_{\mathrm{t}} & =25.55\left[1-\mathrm{e}^{-0.3573(\mathrm{t}+0.81)}\right] \\
\mathrm{W}_{\mathrm{t}} & =103.56\left[1-\mathrm{e}^{-0.3573(\mathrm{t}+0.81)}\right]^{2.68904}
\end{aligned}
$$


Table (4) Mean calculated length and weight, corresponding values estimated from von Bertalanffy formulae for S.aurita caught by purse seine net using light, east of Alexandria, 2007.

\begin{tabular}{|c|c|c|c|c|}
\hline \multirow[t]{2}{*}{ Age Group } & \multicolumn{2}{|c|}{ Mean length $(\mathrm{cm})$} & \multicolumn{2}{|c|}{ Mean Weight ( gm ) } \\
\hline & Back - calc. & v.B. & Back-calc. & v.B. \\
\hline $\mathrm{I}$ & 12.24 & 12.08 & 14.31 & 14.09 \\
\hline II & 15.90 & 16.2 & 28.93 & 30.36 \\
\hline III & 18.98 & 19.01 & 46.57 & 46.7 \\
\hline IV & 21.36 & 20.98 & 63.98 & 60.87 \\
\hline V & 22.17 & 22.35 & 70.71 & 72.22 \\
\hline
\end{tabular}

\section{1-v - Growth performance index:}

The obtained results indicated that this index $(\varnothing)$ of $S$. aurita was found to be: $\varnothing=2.368$.

1 - vi - Maximum age ( $\mathbf{t}$ max.) was estimated after Pauly (1983) as t max = $3 / \mathrm{k}+$ to. The value was found to be 7.59 year.

\section{2-Mortality:}

\section{2 - i - Total mortality (Z)}

Fig. (15) shows the catch curve of S.aurita. The descending portion of the curve was used to calculate the instantaneous total mortality $(\mathrm{Z})$. The computed value was found to be 1.467 . The annual rate of mortality $\left(A=1-e^{-Z}\right)$ was found to be equal to $77 \%$.

Survival rate $(\mathrm{S}=1-\mathrm{A})$ was found to be $23 \%$.

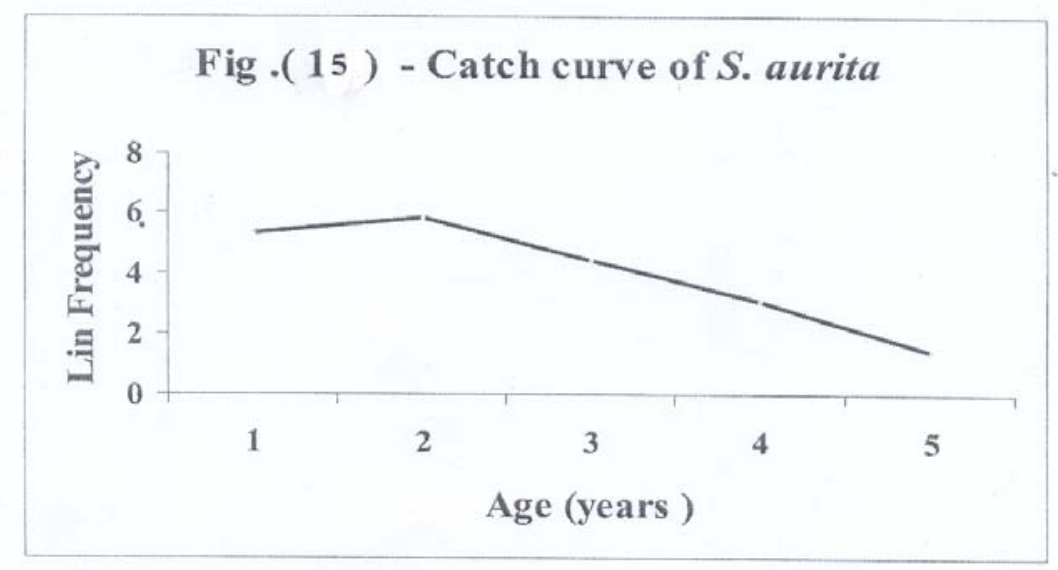

\section{2 - ii - Natural mortality (M) and Fishing mortality (F):}

Natural mortality as estimated by Pauly (1980) was found to be 0.86959 . The fishing mortality $(\mathrm{F})$ could be obtained from the relation $\mathrm{Z}=\mathrm{M}+\mathrm{F}$, which was proved to be $\mathrm{F}=0.59741$. 
2 - iii - Rate of exploitation (E): The exploitation rate was found to be 0.31336 .

2 - iv - Length (Lc) and age (tc) at first capture: Length at first capture was calculated according to Beverton \& Holt (1957). The value of Lc was found to be $13.25 \mathrm{~cm}$ and its corresponding age tc was 1.24 year.

$2-v-$ Length (Lr) and age (tr) at recruit:

The cumulative curve of proportions of recruits against the corresponding lengths was used graphically to determine length at recruitment (Lr) (Fig. 16). It was found that S.aurita fully recruited at $14.5 \mathrm{~cm}$. The corresponding age (tr) as derived from von Bertalanffy equation was proved to be 1.54 year.

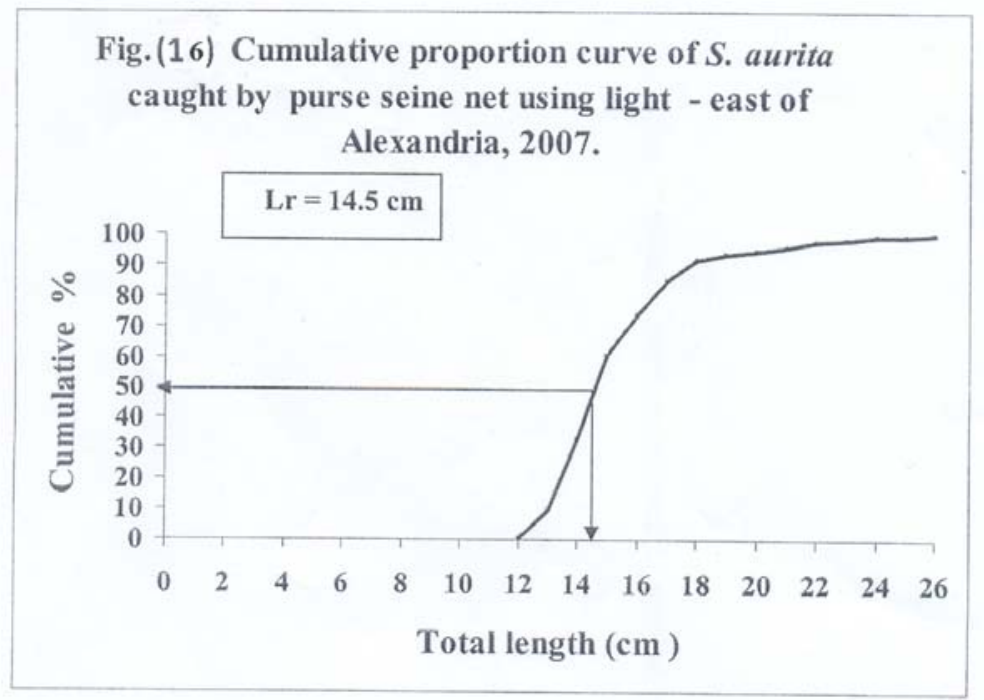

\section{3 - Yield per recruit (Y / R):}

The equilibrium yield, as calculated according to the parameters of growth and mortality for S. aurita, was plotted against fishing mortality in Fig.(17). The input parameters were: $\mathrm{M}=0.86959, \mathrm{~W}_{\infty}=103.56 \mathrm{~g}, \mathrm{~K}=0.3573$, $\mathrm{t}_{\mathrm{o}}=-0.81, \mathrm{tc}=1.24, \mathrm{tr}=1.54$ year . The results obtained show that the yield per recruit increased continuously as the fishing mortality $(\mathrm{F})$ increased, reaching the maximum sustainable yield (MSY) $(18.5 \mathrm{gm})$ at fishing mortality $\mathrm{F}=2.8$. At the level of fishing mortality operating ( $\mathrm{F}=0.59741)$, the current yield per recruit (CY) reached $13.5 \mathrm{~g}$. As the maximum economic yield (MEY) is a preferable target in the fishery management (Beverton \& Holt, 1957), was attained in the present study at the exploitation rate $(0.5066)$ and $(\mathrm{MEY})$ was found equal to $16.7 \mathrm{~g}$. 
4-Biomass: The biomass was computed at current yield, maximum economic yield and maximum sustainable yield and it was found equal to 22.6; 13.9 and $6.6 \mathrm{~g}$ respectively (Table 5 ).

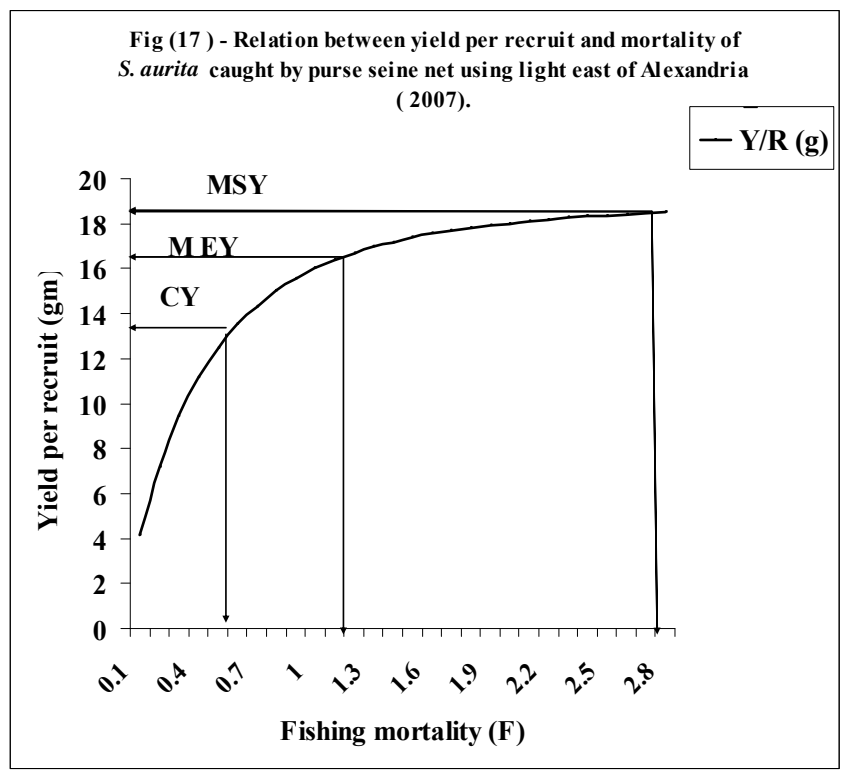

Table. (5): Fishing mortality, yield per recruit, exploitation and biomass at different exploitation levels for $S$. aurita caught by purse seine net using light, east of AlexandriaEgypt (2007).

\begin{tabular}{|c|c|c|c|c|}
\hline Exploitation levels & $\begin{array}{c}\text { Fishing } \\
\text { Mortality } \\
(\mathrm{F})\end{array}$ & $\begin{array}{c}\text { Yield per Recruit } \\
(\mathrm{Y} / \mathrm{R})\end{array}$ & $\begin{array}{c}\text { Exploitation } \\
\text { rate ( E ) }\end{array}$ & $\begin{array}{c}\text { Biomass } \\
(\mathrm{B})\end{array}$ \\
\hline 1 - Current & 0.60 & 13.5 & 0.3134 & 22.6 \\
\hline 2- Maximum (economic) & 1.2 & 16.7 & 0.5066 & 13.9 \\
\hline 3- Maximum (sustainable ) & 2.8 & 18.5 & 0.7436 & 6.6 \\
\hline
\end{tabular}

\section{DISCUSSION}

After the Nile flood was controlled (1964 - 1966), the hydrology of the Mediterranean Egyptian coast was changed considerably. This has changed the situation of distribution and abundance of many fish species. The relative increase in the salinity of the sea water had encouraged the migration of some Red Sea species into the Mediterranean Sea.

During 2006, sardine production compared to pelagic fish production in some Mediterranean countries was found to be as follows: Egypt $47 \%$; Tunis 22 $\%$; Israel 11\%; Spain $5 \%$; Italy $4 \%$ and Morocco $2 \%$ (www.faofishbase.org/).

The present study revealed that sardine species dominated the catch of purse seine using light (72\%). This result agrees with other studies; Hashem et al. (1982) reported that Clupeidae dominated the catch of purse seiners using 
light (68 \%) followed by E. enchrasicholus; B.boops; T. mediterraneus; S. japonicus; Temnodon saltator; Lichia glaucus; Sphyraena sphyraena and Euthynnus allettratus. Faltas (1983) recorded that the sardine percentage reached $69 \%$ of the total catch, followed by E. enchrasicholus; B.boops; S. japonicus; T. mediterraneus; Trachynotus ovatus; T. saltator; E. allettratus and Sphyraena spp.Wassef et al. (1985) reported Clupeidae as the dominant constituents of the purse seine catch using light operating off Alexandria (69\%) followed by $E$. enchrasicholus; B.boops; T.mediterraneus; S. japonicus; T. saltator and Trachynotus ovatus.

GAFRD (2007) reported that the Egyptian Mediterranean total catch was dominated by sardine species ( $24 \%$ ).

From the above studies and the present one, it seems that sardine catch was always and still representing the major target and its catch ranked the first in pelagic fish species landings along the Egyptian Mediterranean coast.

It is worthy to mention that nowadays two migrating sardine species from the Red Sea were established in the Egyptian Mediterranean waters of Egypt: $H$. punctaus (Whitehead, 1985) and E. teres (El- Sayed, 1994). Reviewing the present study, the catch of sardine could be distinguished into three important species; S. aurita E. teres and S. pilchardus. Scomber japonicus and Boops boops attained the second and third important positions after sardine, while this percentage was lower as given by Faltas (1983). This means that the environment became favorable for these species, while Trachurus mediterraneus came fourth in abundance in the purse seine catch and it was the same as given by Faltas (1983). For Engraulis encrasicholus, this species occupied the fifth place of abundance in the catch during the present study, while its level was very high as given by Faltas (1983). This revealed that environmental conditions became unfavorable for this species.

There are fluctuations in sardine production as well as small pelagic fish species and this well known phenomenon. Fluctuation in purse seine catch is greatly related to the abundance of the migratory pelagic fish caught by such net, to the climatic and prevailing environmental conditions (Nakai et al, 1960). The fluctuation of fish populations may be affected by many factors: such as water temperature, shift of currents and changes of sea level and wind stress (Cushing, 1982; Kawasaki, 1985).

Regarding the size composition of species: The average length, of S.aurita in the present study showed a decrease from large sizes in spring time to smaller sizes in summer time. The same finding coincided with that given by Faltas (1983), where the larger sizes were observed in the beginning of the fishing season and decreased gradually by the end of fishing season. As regards E.teres, this migratory species from the Red Sea, was caught in big sizes in spring time, while smaller ones in summer time. Sanders and Kedidi (1984) found that the total length of this species ranged between 11 and $23 \mathrm{~cm}$ in the Suez Gulf, while the total length of this species varied between 7 and $18 \mathrm{~cm}$ in the Mediterranean 
waters. S.pilchardus, B. boops and T. mediterraneus were found in relatively smaller sizes in the present study than those caught by Faltas (1983). Regarding E. encrasicholus, in the present study, the large sizes and older fishes caught in spring time were found the same as recorded by Sanders and Kedidi (1984) in the Gulf of Suez. Due to the instability of the stock, a continuous monitoring of the stock and abundance should be guaranteed by scientific surveys independently from commercial catch based data in order to detect any unforeseen changes which could demand urgent management measures.

Growth is the most important characteristic with which various biologists have been concerned since a long time. It is specific for each fish species and has an adaptive property, ensured by the unity of the species and its environment (Weatherly, 1972).

The back calculated length data of S.aurita given by different authors as well as of the present study are presented as follows:

\begin{tabular}{|l|c|c|c|c|c|}
\hline \multirow{2}{*}{ Author and Country } & \multicolumn{5}{|c|}{ Calculated fish length at the end of each year of life (cm) } \\
\cline { 2 - 6 } & \multicolumn{5}{|c|}{ Age (years) } \\
\cline { 2 - 6 } & 1 & 2 & 3 & 4 & 5 \\
\hline El- Maghraby (1960), Egypt. & 12.4 & 16 & 19.2 & 21.9 & 23.8 \\
\hline El-Maghraby et al (1970),Egypt & 12.4 & 14.7 & 16.4 & 18.1 & \\
\hline Faltas (1983), Egypt. & 12.4 & 15.7 & 18.6 & 21.3 & 23.4 \\
\hline Tsikliras et al ,(2005), Greece & 13.7 & 17.4 & 19.4 & 21.1 & 22.9 \\
\hline Present study (2007), Egypt. & 12.24 & 15.9 & 18.98 & 21.36 & 22.17 \\
\hline
\end{tabular}

From the above data, it is obvious that the back calculated lengths of S.aurita obtained by Faltas (1983) are nearly close to those of this study, which were caught from the same area. Therefore, a statistical analysis has been done revealing highly insignificant differenence between data obtained by Faltas (1983) and the present study $(\mathrm{t}=0.588, \mathrm{df}=8, \mathrm{p}<0.05)$.

The growth parameters of von Bertalanffy's equation as estimated previously by various authors in different localities for $S$. aurita, and that of the present study, are illustrated as follows:

\begin{tabular}{|l|c|c|c|c|}
\hline \multicolumn{1}{|c|}{ Author and Country } & L & $\mathrm{K}$ & $\mathrm{t}_{\mathrm{o}}$ & $\varnothing$ \\
\hline Pauly, (1978), Brazil. & & & & \\
\hline Tsikliars et al (2005), Greece. & 24.5 & 0.423 & -1.23 & 2.40 \\
\hline Pauly, (1978), Spain. & 25 & 0.494 & -0.86 & 2.49 \\
\hline AO Rapp. Péches (266), (1982) Tunisia. & 27.7 & 0.447 & -1.41 & 2.54 \\
\hline Gheno, (1975), Congo. & 29 & 0.362 & -0.92 & 2.48 \\
\hline Pauly, (1978), Israel. & 30.6 & 1.023 & -0.09 & 2.98 \\
\hline Pauly, (1978), Canary Islands. & 31.1 & 0.250 & -1.81 & 2.38 \\
\hline Abdalla, and El- Haweet, (2000) Egypt. & 37 & 0.257 & -0.82 & 2.55 \\
\hline Present study (2007), Egypt. & 36.5 & 0.45 & -0.35 & 2.78 \\
\hline
\end{tabular}

The asymptotic length $(\mathrm{L} \infty)$ in the present study $(25.55 \mathrm{~cm})$ accords with the results in other localities. The highest value $(36.5 \mathrm{~cm})$ was recorded by Abdalla \& El- Haweet (2000) in Egyptian Mediterranean waters, while the lowest one $(24.5 \mathrm{~cm})$ was recorded by Pauly (1978) in Brazil. The growth coefficient (K) in 
the present study $(0.3537)$ falls within those in other localities. The greatest value (1.023) was recorded by Gheno (1975) in Congo, while the lowest value (0.250) was reported by Pauly (1978) in Israel.

Considering prenatal age $\left(\mathrm{t}_{\mathrm{o}}\right)$ the value obtained in the present study $(-0.81)$ was in between the corresponding values in other localities. The highest value (-1.41) was reported by Pauly (1978) in Spain, while lowest value (-.09) was recorded by Gheno (1975) in Congo.

Growth performance $(\varnothing)$ in the present study (2.37) was found nearly similar to that recorded by Pauly (1978) in Israel, while higher value was reported by Abdalla \& El-Haweet (2000) in Egyptian Mediterranean waters. The disagreement between the growth parameters and those of the present study were confirmed statistically by using analysis of variance (ANOVA), where a highly significant difference was statistically estimated $(\mathrm{d} \mathrm{f}=3,32), \mathrm{P}>2.90558)$. This difference is ascribed to varying conditions between different areas.

Estimates of mortalities from the present study and that of Faltas (1983) and Abdalla \& El-Haweet (2000), are presented in the following table:

\begin{tabular}{|l|c|c|c|c|c|c|}
\hline \multicolumn{1}{|c|}{ Author } & Z & S & A & F & M & E \\
\hline Faltas (1983). & 1.7818 & 0.17 & 0.83 & 0.7503 & 1.0314 & 0.5278 \\
\hline Abdalla, and El- Haweet,.(2000), Egypt. & 2.910 & 0.06 & 0.94 & 2.182 & 0.728 & 0.71 \\
& & & & & & \\
\hline Present study (2007), Egypt. & 1.467 & 0.23 & 0.77 & 0.5974 & 0.8695 & 0.3133 \\
\hline
\end{tabular}

Concerning the instantaneous total mortality $(\mathrm{Z})$, the value in the present study has the lowest one (1.467), while those given by Abdalla \& El-Haweet (2000) got highest value (2.91). Survival rate in the present study was found to be higher (0.23) than that given by Faltas (1983) and Abdalla\& El-Haweet (2000) being 0.17 and 0.06 respectively. Annual mortality attained the least value in the present study while the highest value (0.94) was recorded by Abdalla \& El- Haweet (2000). As for fishing mortality, it was lower in the present study (0.5974), while higher fishing effort (2.182) was recorded by Abdalla\& El- Haweet (2000). Estimation of exploitation rate in the present study (0.31336) revealed that S.aurita is under-exploited, while it was shown to be over exploitation (0.71) as reported by Abdalla \& El- Haweet (2000). This means that fishing effort exerted became lower and favorable for this fish species. Gulland (1971) mentioned that exploitation ratio should not exceed 50 $\%$ for the optimum condition of exploitation. The ANOVA test was applied to test differences of the mortalities between the present study, and previous studies. The test revealed that there was a high significant difference $(\mathrm{d} \mathrm{f}=5,6)$, $\mathrm{P}>4.3874$, and this can be attributed to the fact that in the previous studies fishes were collected from both east and west of Alexandria, while in the present study, fishes were caught only from east of Alexandria. 


\section{REFERENCES}

Abdalla, M. and El- Haweet, A. (2000). Stock Assessment of Sardine In The Egyptian Mediterranean Waters By virtual Population Analysis: Case For The Coast From Alexandria To Abu Qir. Egypt. J. Aquat. Biol. \& Fish., 4 (3): 173 - 191.

Beverton, R.J.H. and Holt, S.J. (1957). On the dynamics of exploited fish populations. Fish. Invest. London, Ser., 2 (19): 533pp.

Conseil Général Des Péches Pour La Méditerranée, (198Yr). Report de la premiér consultation technique sur l' evaluation des stocks dans Méditerranée Central - Tunis. (1982). FAO Rapp. Peches (266): 125pp. FAO, Rome.

Cushing, D.H. (1968). Fisheries biology. A study of population dynamics. Univ. Wisconsin Press, Madison, 200pp.

Cushing, D.H. (1982). Climate and Fisheries. Academic Press, New York, 373pp.

Cushing, D.H. and Verheijen, F.J. (1960). Fluctuation and Sardine behavior .IN: Proc. World .Sci. Meet. .Biol. Sardines \& related sp. FAO, Section Report 5.

El-Maghraby, A.M. (1960). The biology of the Egyptian Sardine Preliminary account of the biology of Sardinella eba Cuv. \&Val. Notes and Memoires no.58, Alexandria,. Inst. Hydrob.

El-Maghraby, A.M.; Botros, G.A. and Soliman, I.A.M. (1970). Age and growth studies on Sardinella maderensis Lowe and Sardinella aurita Cuv.and Val., from the Mediterranean Sea at Alexandria. (U.A.R.) Bull. Inst. Oceanogr.Fish.Cairo, 1: 47 - 82

El-Sayed, R.S. (1994). Check list of Egyptian Mediterranean Fishes. National Inst. of Oceanog. And Fish. Alexandria, Egypt. 77 pp + IX plates.

Faltas, S.N. (1983). Study Of Purse Seine Fisheries In Egyptian Mediterranean Waters With Special Reference To The Biology Of Sardine In The Catch. M. Sc. Thesis, Fac. Science, Alexandria Univ.,200 pp.

Faltas, S.N. and Akel, E.H. Kh. (2003). Investigation Of Beach Seine Catch Of Abu Kir Bay (Egypt).Bull. Nat. Inst. of Oceanogr. \& Fish., A.R.E., (29): 117 - 135 . 
Fulton, H. (1902). Rate of growth of sea fishes. Sci. Invest., Fish. Div. Scot. Rept. 20.

GAFRD, (2007). General Authority for Fish Resources Development Annual Fishery Statistics Report.

Gheno, Y. (1975). Nouvelle études sur la détermination de Tâge et de la croissance de Sardinella aurita Val.Cah. O.R.S.T.O.M.Sér. Oceanogr. 13 (3): 251-262.

Gulland, J.A. (1969). Manual of methods for fish stock assessment Part 1 - Fish population analysis. FAO, Fish .Tech. Rep.4: 154pp http://www.fishbase.org/

Imamura, Y. and Tackeuchi, S. (1960). Study on the disposition of Engraulis japonicus, Decapterus muroadsi, Trachurus japonicus and Scomber japonicus. J. Tokyo Univ. of fishery, $46(1-2)$.

Kawasaki, T. (1985). Fisheries. In: Kates, R.W., Ausbel, J.H.and Berberian, M. (Eds.), Climate Impact Assessment. Wiley, New York; pp.131- 153.

Koutrakis, E.; Trikliras, A. and Kllianiotis, A. (2001). Small Pelagic Fishery Using Sardine Net in the Gulf of Kavala (Northern Aegean Sea).General Fisheries Commission for the Mediterranean Scientific Advisory Committee. Nea. Peramos Kavala. Greece.

Le Cren, E.D. (1951).The length - weight relationship and seasonal cycle in gonad weight and condition in the perch (Perca fluviatilis). J. Animal Ecology, 20: 201- 218

Lee, Rosa M. (1920). A review of the methods of age and growth determination in fishes by means of scales. Min. Agr. and Fish. Fish. Invest. Ser. II, $4(2): 1-32$.

Nakai, Z.; Murphy, G.I. and Radovich, J. (1960).Fluctuations and abiotic factors. In: Proc. World Sci. Meet. Biol. Sardine and related sp., FAO, Section Report, 2.

Pauly, D. (1978). A preliminary compilation of fish length growth parameters. Ber. Inst. Meeresk .Christian - Albrechts- Univ. Kiel, 55: 1-200.

Pauly, D. (1980). On the interrelationships between natural mortality, growth parameters and mean environmental temperature in 175 fish stocks. J. Cons. CIEM, 39 (3): 175 - 192. 
Pauly, D. (1983). Length - converted catch curves .A powerful tool for fisheries research in the tropics. Part 1 .ICLARM Fish Byte, 1 (2):9- 13.

Pauly, D. and Munro, J.L. (1984). Once more on the comparison of growth in fish and invertebrates. ICLARM Fish byte, 2 (1): 21.

Rafail, S.Z. (1972). Studies of Red Sea fisheries by light and purse seine near Al- Ghardaka .Bull.Inst. Fish. A.R.E., 2: 23 - 49.

Ricker, W.E. (1975). Computation and interpretation of biological statistics of fish populations. Bull. Fish. Res.Bd .Can., (191) 382pp.

Sanders, M.J. and Kedidi, S.M. (1984). Stock Assessment for the Round Herring (Etrumeus teres) Caught by Purse Seine in the Gulf of Suez. FAOProject For development of Fisheries in areas of the Res Sea and Gulf of Suez.

Soliman, I.A.M.; Botros, G.A. and El - Maghraby, A.M. (1970). Length-weight relationship and coefficient of condition for Sardinella maderensis Lowe and Sardinella aurita Cuv. and Val. From the Mediterranean Sea at Alexandria. (U.A.R.) Bull. Inst. Oceanogr. Fish. Cairo,1: 27- 45.

Tsilkliars, A.C.; Koutrakis, E.T. and Stergiou, K.L. (2005).Age and growth of round sardinella (Sardinella aurita) in the northern Mediterranean. Sci. Mar., 69(2): 231-240.

Wassef, E.; Ezzat, A.; Hashem, T. and Faltas, S.N. (1985). Sardine Fishery by Purse Seine on The Egyptian Mediterranean Coast, Mar. Ecol.Prog. Ser. 26: $11-18$.

Weatherly, A.H. (1972). Growth and ecology of fish populations. Academic Press, London, 293pp.

Whitehead, P.J.P. (1985). FAO species catalogue 7. Clupeoid fishes of the world (Suborder: Clupeoidei). An annoted and illustrated catalogue of the herrings, sardines, pilchards, sprats, shads, anchovies and wolfherrings. Part I- Chirocentridae, Clupeidae and Pristigasteridae. FAO Fish. Synop., 125 (7 / 1): $1-30$. 